\title{
Barksterameðferð við erfiðum lungnasjúkdómi hjá fyrirburum
}

Erna Hinriksdóttir ${ }^{1}$ læknanemi, Hrólfur Brynjarsson² læknir, Pórður Pórkelsson ${ }^{1,2}$ læknir

\section{ÁGRIP}

Tilgangur: Margir fyrirburar með erfiðan lungnasjúkdóm eru meðhöndlaðir með barksterum í æð eða á úðaformi i peim tilgangi að̃ ná peim af öndunarvél og/eđa minnka súrefnispörf peirra. Umdeilt er hvort ávinningurinn af meðferđinni sé nægur til að̃ vega upp á móti hugsanlegum aukaverkunum, einkum sterameðferðar í æð. Megintilgangur rannsóknarinnar var að kanna áhrif barksterameðferðar í æð eða á úđaformi á pörf fyrirbura fyrir öndunarvélameðferð og súrefnisgjöf og kanna hugsanlegar aukaverkanir meðferðarinnar.

Efniviður og aðferðir: Rannsóknin var afturskyggn hóprannsókn á fyrirburum á vökudeild Barnaspítala Hringsins, fæddum 2000-2014, sem fengu barksterameðferð i æð ( $n=28)$ eða á úđaformi $(n=30)$ við erfiðum lungnasjúkdómi. Eitt viðmið var valið fyrir hvert tilfelli, parað á meðgöngulengd. Niðurstöður: Marktæk lækkun varð á súrefnispörf barna sem fengu barkstera í æð eða á úðaformi fyrstu dagana eftir að meðferð hófst en ekki hjá viðmiðum. Marktækt fleiri tilfelli en viðmið burftu öndunarvélameðferð við upphaf steragjafar í æð, en ekki fjórum dögum síðar. Marktækt minni pyngdaraukning varð hjá tilfellum sem fengu stera i æð en viðmiðum á meðferðartímabilinu, en við 35 vikna meðgöngualdur var ekki marktækur pyngdarmunur milli hópanna tveggja. Ekki reyndist marktækur munur á öđrum hugsanlegum aukaverkunum milli hópanna, svo sem tíðni heilalömunar.

Ályktanir: Barksterameðferð i æð eða á úðaformi minnkar súrefnispörf fyrirbura og barksteragjöf í æð flýtir pví að börnin náist af öndunarvél, án verulegra aukaverkana. Pví kemur til greina að nota barkstera hjá fyrirburum með erfiðan lungnasjúkdóm í völdum tilvikum.
'Læknadeild Háskóla Íslands, ${ }^{2}$ Barnaspítali Hringsins, Landspítala.

Fyrirspurnir: Pórður Pórkelsson thordth@landspitali.is

Greinin barst 14. desember 2015, sambykkt til birtingar

14. mars 2016.

Höfundar hafa útfyltt eyðublað um hagsmunatengsl.

\section{Inngangur}

Eitt helsta vandamál fyrirbura er lungnavanproski. Hjá minnstu fyrirburunum hafa eiginlegar lungnablöðrur ekki myndast við fæðingu, pannig að loftskipti purfa að fara fram í gegnum forstig peirra (sacculi). ${ }^{1}$ Einnig er háræðabeðurinn, sem seinna umlykur lungnablöðrurnar, ekki enn fullmyndaður. Framleiðsla á lungnablöðruseyti (pulmonary surfactant) hefur ekki hafist eða er lítil. Flest pessara barna purfa pví á öndunaraðstoð og súrefnismeðferð að halda fyrstu dagana og jafnvel vikurnar eftir fæðingu. Sú meðferð veldur álagi á lungun, sem leitt getur til bólgusvörunar með háræðaleka, pannig að próteinríkur vökvi safnast í lungun, sem minnkar eftirgefanleika (compliance) peirra og truflar loftskipti. ${ }^{2}$ Petta eykur öndunarvandamál barnanna enn frekar og pví getur pörf peirra fyrir öndunarstuðning og súrefnismeðferð orðið langvarandi. Ástand petta hefur verið kallað langvinnur lungnasjúkdómur (LLS) hjá fyrirburum (chronic lung disease of prematurity, bronchopulmonary dysplasia) og er í dag yfirleitt skilgreint sem pörf fyrir súrefnisgjöf við 36 vikna meðgöngualdur (postmenstrual age).,34

Barksterar hafa verið notaðir til að meðhöndla og fyrirbyggja LLS hjá fyrirburum. Sýnt hefur verið fram á að gjöf barkstera í æð minnkar pörf peirra fyrir öndunaraðstoð og líkur á að peir fái LLS, auk pess sem lífslíkur aukast. ${ }^{5}$ Hins vegar hefur meðferðin verið umdeild, par sem rannsóknir hafa sýnt að hún hefur í för með sér auknar líkur á heilalömun (cerebral pal$s y, \mathrm{CP})$ og annarri proskaskerðingu. ${ }^{6}$ Í flestum pessara rannsókna voru hins vegar notaðir hærri skammtar af barksterum en venja er í dag. ${ }^{7}$

Barksterameðferð á úðaformi er talin valda minni aukaverkunum en meðferð í æð og sýndi nýleg stór rannsókn að hún dregur úr líkum á LLS hjá minnstu fyrirburum. ${ }^{8}$

Tilgangur rannsóknarinnar var að kanna notkun barkstera við erfiðum lungnasjúkdómi hjá fyrirburum á vökudeild Barnaspítala Hringsins yfir 15 ára tímabil (2000-20014). Metin voru áhrif meðferðar á pörf barnanna fyrir öndunarvélameðferð og súrefnisgjöf, auk pess sem hugsanlegar aukaverkanir meðferðar voru kannaðar. Jafnframt var próun pessar meðferðar á rannsóknartímabilinu skoðuð.

\section{Efniviður og aðferðir}

Rannsóknin var afturskyggn hóprannsókn (retrospective cohort study) á peim fyrirburum á vökudeild Barnaspítala Hringsins, sem á árunum 2000-2014 fengu barksterameðferð í æð eða á úðaformi í peim tilgangi að minnka súrefnispörf peirra og ná peim af öndunarvél. Pau börn sem fengu bæði stera í æð og á úðaformi voru höfð í rannsóknarhópi með börnum sem fengu eingöngu stera í æð. Fyrir hvert barn sem fékk sterameðferð var fundið 


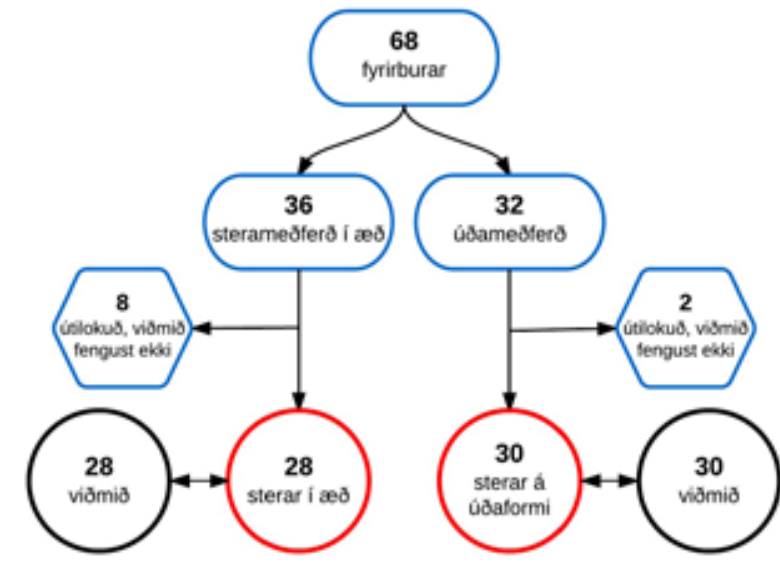

Mynd 1. Skipting barnanna í hópa.

sem viðmið eitt barn sem ekki fékk sterameðferð, parað á meðgöngulengd. Einnig var leitast við að para börnin á fæðingarári. Öll börnin voru fundin í Vökudeildarskránni, sem er upplýsingagrunnur um öll börn sem leggjast inn á vökudeildina.

Klínískra upplýsinga var aflað úr sjúkraskrám barnanna og mæðraskrám. Aflað var upplýsinga um meðgöngu, fæðingu og ástand barnsins við fæðingu. Við ákvörðun á meðgöngulengd var miðað við niðurstöður ómskoðana við 18.-20. viku meðgöngu. Fæðingarpyngd, lengd og höfuðummál barnanna var skráð.

Um börnin sem fengu sterameðferð var aflað upplýsinga um aldur við upphaf og lok meðferðar, form meðferðar (í æð eða á úðaformi) og upphafsskammt miðað við líkamspyngd. Skráð var meðalsúrefnispörf og pörf fyrir öndunaraðstoð 5 dögum áður en sterameðferð hófst, daginn sem meðferðin hófst, daglega næstu vikuna og 10 og 14 dögum eftir upphaf meðferðar. Sömu upplýsinga var aflað um börnin í viðmiðunarhópnum við sama aldur og börnin sem pau voru pöruð við. Svörun barnanna við sterameðferðinni var metin með pví að reikna út meðalsúrefnispörf peirra sem fengu stera og kannað hvernig hún breyttist á meðferðartímabilinu, auk pess sem súrefnispörfin var borin saman við súrefnispörf barnanna í viðmiðunarhópnum. Í sama tilgangi var fundinn fjöldi barna sem purfti á öndunarvélameðferð að halda á meðferðartímabilinu og sams konar samanburður gerður og á súrefnispörfinni.

Til að kanna hugsanlegar aukaverkanir sterameðferðar var skráður blóðsykur barnanna daginn sem meðferð hófst og premur dögum síðar. Skráð var pyngd, lengd og höfuðummál barnanna við upphaf og lok sterameðferðar, og við 35 vikna meðgöngualdur. Samsvarandi upplýsinga var aflað fyrir börnin í viðmiðunarhópnum við sama aldur og börnin sem pau voru pöruð við. Skráður var fjöldi grunaðra sýkinga og sýkinga sem staðfestar voru með ræktunum á tímabilinu frá upphafi sterameðferðar par til tveimur vikum eftir að henni lauk. Einnig var skráð hvort börnin fengu heilablæðingu og pá af hvaða gráðu, eða greindust með heilalömun. Pessar breytur voru bornar saman milli barnanna í meðferðarhópunum og viðmiðahópunum.

Öll gögn voru skráð í tölfræðiforritið JMP ${ }^{\circledR}$ - SAS Institute Inc. og tölfræðiúrvinnsla unnin í pví. Óparað t-próf var notað pegar bornar voru saman samfelldar breytur milli tveggja hópa og parað t-próf pegar bornar voru saman breytingar á samfelldum breytum
Mynd 2. Samanburður á súrefnispörf barna sem fengu sterameðferð í æð og barna í viðmiðunarhópi.

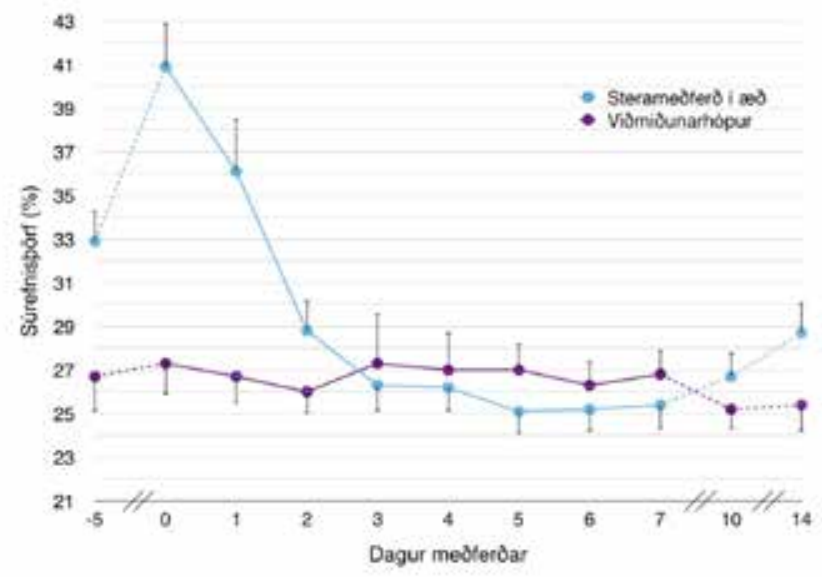

Súrefnispörf barnanna frá pví 5 dögum fyrir og par til 14 dögum eftir upphaf meðferðar. Dagur 0 er upphafsdagur meðferðar.

- Samanburdur á súrefnispörf milli daga hjá meðferðarhópi: Dagur -5 og 0, p<0,001; dagur 0 og 1, p=0,01; dagur 1 og 2, p<0,001; dagur 2 og 3, p=0,01; dagur 7 og 14, $p=0,03$; ekki var marktækur munur á breytingu á súrefnispörf milli annarra samliggjandi daga.

- Samanburður á súrefnispörf meðferðarhóps og viðmiðunarhóps: Dagur -5, p=0,005; dagur 0, p<0,001; dagur 1, p=0,001; ekki var marktækur munur á súrefnispörf milli hópanna á öđrum dögum.

milli tveggja tímabila innan sama hóps. Kí-kvaðrat var notað til að bera saman ósamfelldar breytur milli tveggja hópa. Niðurstöður eru gefnar upp sem hlutfallstölur, meðaltöl \pm staðalfrávik eða miðgildi og spönn eftir pví sem við á. Í skýringarmyndum er meðaltal \pm staðalskekkja notað til að sýna dreifingu. Tölfræðileg marktækni er miðuð við $\mathrm{p}<0,05$.

Rannsóknin var sampykkt af siðanefnd Landspítala og Persónuvernd. Jafnframt var fengið leyfi hjá framkvæmdastjóra lækninga á Landspítalanum.

\section{Niðurstöður}

Sextíu og átta fyrirburar fengu sterameðferð vegna erfiðs lungnasjúkdóms á vökudeild Barnaspítala Hringsins á árunum 20002014. Af peim fengu 36 stera í æð og 32 stera á innúðaformi eingöngu. Ekki tókst að finna viðmið fyrir 8 börn sem fengu stera í æð og tvö börn sem fengu stera á úðaformi. Pannig fengust í samanburðarhluta rannsóknarinnar 28 börn sem fengu stera í æð og 30 börn sem fengu stera á úðaformi og jafn mörg viðmið (mynd 1).

\section{Sterameðferð i æð}

Ekki reyndist marktækur munur milli barnanna sem fengu stera í æð og viðmiða á helstu klínísku páttum sem varða móður, meðgöngu, fæðingu og barnið sjálft (tafla I).

Öll börnin í rannsókninni sem fengu stera í æð fengu dexametason (Decadron $\left.{ }^{\circledR}\right)$. Sex börn höfðu fengið úðameðferð áður en sterameðferð í æð hófst og prjú börn fengu fleiri en einn kúr af dexametasón í æð. Meðalaldur barnanna sem fengu stera í æð var 22,6 \pm 9,6 dagar (miðgildi 21; spönn 8-55) við upphaf meðferðar. Að meðaltali var sterameðferðin í æð 10,2 \pm 8,0 daga löng (miðgildi 8; spönn 2-46) og voru skammtarnir minnkaðir smám saman áður en meðferð var hætt. 
Mynd 3. Samanburður á fjölda barna á öndunarvél sem fengu stera í æð og barna í viðmiðunarhópi.

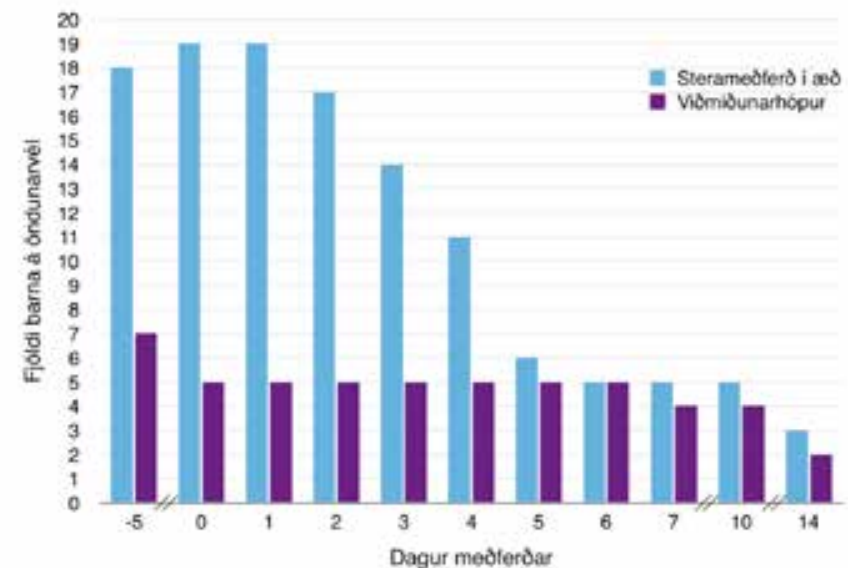

Fjöldi barna á öndunarvél frá pví 5 dögum fyrir og par til 14 dögum eftir upphaf meðferðar. Dagur 0 er upphafsdagur meðferðar.

- Samanburdur á fjölda barna á öndunarvél sem fengu stera í æð: Dagur 0 og 4, p=0,03. - Samanburður á fjölda barna á öndunarvél milli meðferðarhóps og viðmiðunarhóps: Dagur -5, $p=0,003$; dagur 0, $p<0,001$; dagur 1, $p<0,001$; dagur 2, $p<0,001$; dagur 3, $p=0,01$; ekki var marktækur munur milli hópanna eftir pað.

Meðalupphafsskammtur af dexametason sem gefinn var í æð var 0,27 $\pm 0,11 \mathrm{mg} / \mathrm{kg}$ (miðgildi 0,24; spönn 0,12-0,55). Upphafsskammtur barna sem fædd voru á árunum 2000-2002 $(\mathrm{N}=13)$ var að meðaltali $0,37 \pm 0,12 \mathrm{mg} / \mathrm{kg} /$ sólarhring (miðgildi 0,37; spönn 0,23-0,55), en upphafsskammtur barna sem fædd voru á árunum 2005-2014 ( $\mathrm{N=23)}$ var að meðaltali $0,20 \pm 0,05$ $\mathrm{mg} / \mathrm{kg} /$ sólarhring (miðgildi 0,20; spönn 0,12-0,29), p<0,001. Árin 2003 og 2004 fékk ekkert barn stera í æð sem meðferð við LLS. Af peim börnum sem lögðust inn á deildina á rannsóknartímabilinu og voru $<1500$ g við fæðingu, fengu 8,3\% (36/436) stera í æð. Árin 2000-2002 voru pað 15,6\% (14/90) barnanna, en 6,4\% (22/346) árin 2005-2014, $\mathrm{p}=0,009$. Af peim börnum sem voru $<1000 \mathrm{~g}$ við fæðingu, fengu 20,3\% (31/153) stera í æð á rannsóknartímabilinu.
Árin 2000-2002 voru pað 35,1\% (13/37) barnanna, en 15,5\% (18/116) árin 2005-2014, $\mathrm{p}=0,028$.

\section{Súrefnispörf og öndunaraðstoð}

Meðalsúrefnispörf barnanna sem fengu sterameðferð í æð var $32,9 \%$ (miðgildi 31,5\%; spönn 21-53) 5 dögum fyrir upphaf meðferðar. Á upphafsdegi sterameðferðar í æð var meðalsúrefnispörf barnanna orðin marktækt hærri, eða 40,9\% (miðgildi 38\%; spönn 23,5-73,5), p<0,001. Daginn eftir upphaf meðferðar hafði meðalsúrefnispörfin lækkað marktækt og var orðin 36,1\% (miðgildi 32,9; spönn 21-77), $\mathrm{p}=0,01$. Á pessu tímabili breyttist súrefnispörf barnanna í viðmiðunarhópi ekki marktækt. Súrefnispörf barnanna í tilfellahópnum hélt áfram að lækka næstu daga eftir upphaf meðferð-

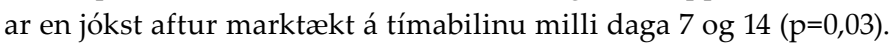
Heildarbreytingin á súrefnispörf barna sem fengu stera í æð var marktæk lækkun milli daga 0 og 14, pað er úr 40,9\% í 28,7\% (miðgildi 26,1; spönn 21-53,8), p<0,001. Á sama tímabili breyttist súrefnispörf barna í viðmiðunarhópnum ekki marktækt (mynd 2).

Við upphaf sterameðferðar og næstu tvo daga par á eftir voru börnin í meðferðarhópnum með marktækt hærri súrefnispörf en börnin í viðmiðunarhópnum, en premur dögum eftir upphaf meðferðar var munurinn ekki lengur marktækur. Á dögum 10 og 14 eftir upphaf meðferðar hafði súrefnispörf barnanna í meðferðarhópnum aukist aftur en sá munur náði pó ekki marktækni á degi $14(\mathrm{p}=0,08)$ (mynd 2).

Við upphaf sterameðferðar voru marktækt fleiri börn í tilfellahópnum en í viðmiðunarhópnum á öndunarvél (19 og 5; $\mathrm{p}<0,001$ ) (mynd 3). Á fyrstu dögum eftir upphaf meðferðar fækkaði börnum í tilfellahópnum sem pörf höfðu fyrir öndunarvél og á fjórða degi eftir upphaf meðferðar var munurinn milli hópanna tveggja ekki lengur marktækur (11 og 5; p=0,07).

Af peim 28 börnum sem fengu sterameðferð í æð purftu 23 (82\%) á aukasúrefni að halda við 36 vikna meðgönguhaldur og fengu pví greininguna LLS, en aðeins 6 af 28 (21\%) í viðmiðunarhópnum

Tafla I. Samanburður á helstu klínísku páttum milli meðferðar- og viðmiðahópa, (\%).

\begin{tabular}{|c|c|c|c|c|}
\hline & \multicolumn{2}{|c|}{ Sterameðferð í æð } & \multicolumn{2}{|c|}{ Sterameðferð á úðaformi } \\
\hline & Sterar í æð & Viðmið & Úðasterar & Viðmið \\
\hline Fjöldi & 28 & 28 & 30 & 30 \\
\hline Aldur móður [ár] & $29,4 \pm 6,6$ & $29,5 \pm 7,9$ & $31,6 \pm 7,2$ & $30,0 \pm 6,0$ \\
\hline Barksterar á meðgöngu: & $25(89,3)$ & $25(89,3)$ & $21(70,0)^{\star}$ & $28(93,3)^{\star}$ \\
\hline > 48 tímum fyrir fæðingu & $17(60,7)$ & $16(57,1)$ & $14(46,7)$ & $20(66,7)$ \\
\hline Fjölburar & $6(21,4)$ & $8(28,5)$ & $10(33,3)$ & $9(30,0)$ \\
\hline Keisaraskurður & $17(60,7)$ & $14(50,0)$ & $20(66,7)$ & $19(63,3)$ \\
\hline Stúlkur & $11(39,3)$ & $16(57,1)$ & $13(43,3)$ & $20(66,7)$ \\
\hline Meðgöngulengd (vikur, dagar) & $\begin{array}{c}26 \mathrm{v} .+3 \mathrm{~d} \\
183,2 \pm 11,6 \mathrm{~d}\end{array}$ & $\begin{array}{c}26 \text { v. }+4 \mathrm{~d} \\
184,0 \pm 11,2 \mathrm{~d}\end{array}$ & $\begin{array}{c}27 \text { v. }+2 \text { d. } \\
191,0 \pm 11,3 d\end{array}$ & $\begin{array}{c}27 \text { v. }+3 \text { d. } \\
191,2 \pm 11,3 \text { d. }\end{array}$ \\
\hline Fæðingarpyngd [g] & $794 \pm 187$ & $853 \pm 282$ & $867 \pm 239$ & $980 \pm 297$ \\
\hline Lengd við fæðingu [cm] & $33,4 \pm 2,9$ & $34,2 \pm 3,2$ & $33,9 \pm 2,8$ & $35,9 \pm 2,9$ \\
\hline Höfuðummál við fæðingu [cm] & $23,5 \pm 1,8$ & $233,4 \pm 2,9$ & $24,5 \pm 2,1$ & $25,1 \pm 2,0$ \\
\hline Apgar við 1 mínútu [miðgildi (spönn)] & $5(1-8)$ & $4(1-8)$ & $4(1-8)$ & $5(1-8)$ \\
\hline Apgar við 5 mínútur [miðgildi (spönn)] & $6(4-10)$ & $6(2-9)$ & $7(2-9)$ & $7(4-9)$ \\
\hline
\end{tabular}

${ }^{*} p=0,016$. Ekki var tölfræðilega marktækur munur á öđrum breytum milli meðferðarhóps- og viðmiðaunarhóps innan rannsóknarhópanna tveggja. 
Tafla II. Samanburður á hugsanlegum aukaverkunum sterameðferðar í æð milli meðferðarhóps og viðmiðahóps (\%).

\begin{tabular}{lccc}
\hline & $\begin{array}{c}\text { Fengu stera } \\
\text { í æð } \mathrm{N}=28\end{array}$ & $\begin{array}{c}\text { Viðmið } \\
\mathrm{N}=28\end{array}$ & p-gildi \\
\hline Pyngd við upphaf meðferðar [g] & $972 \pm 333$ & $980 \pm 333$ & 0,93 \\
\hline $\begin{array}{l}\text { Pyngdaraukning á meðferðartíma } \\
\text { [g/dag] }\end{array}$ & $8,8 \pm 13,9$ & $18,7 \pm 10,9$ & 0,005 \\
\hline
\end{tabular}

Við 35 vikna meðgöngualdur [g]

\begin{tabular}{lccc}
\hline Pyngd & $1901 \pm 245$ & $1890 \pm 410$ & 0,90 \\
\hline Lengd & $41,7 \pm 0,5$ & $42,0 \pm 0,5$ & 0,59 \\
\hline Höfuðummál & $30,8 \pm 0,4$ & $30,5 \pm 0,4$ & 0,63 \\
\hline Sýkingar & & & \\
\hline$\quad$ - grunur um sýkingu & $12(42,9)$ & $11(39,3)$ & 0,79 \\
\hline - sýking staðfest með ræktun & $4(14,3)$ & $6(21,4)$ & 0,51 \\
\hline Heilablæðing & $5(17,9)$ & $4(14,3)$ & 0,72 \\
\hline Heilalömun & $1(3,6)$ & $3(10,7)$ & 0,31
\end{tabular}

(p<0,001). Í innúðahópnum fengu 20 af 30 börnum (67\%) greininguna LLS, sem er ekki marktækt lægra hlutfall en hjá börnum sem fengu sterameðferð í æð $(p=0,17)$.

\section{Hugsanlegar aukaverkanir}

Börnin í meðferðarhópnum pyngdust marktækt minna meðan á steragjöf stóð en börnin í viðmiðunarhópnum á tilsvarandi aldursbili $(8,8 \mathrm{~g} / \mathrm{dag}$ og 18,7 g/dag; $\mathrm{p}<0,01)$. Hins vegar var ekki marktækur pyngdarmunur milli hópanna við 35 vikna meðgöngualdur (tafla II). Ekki reyndist hægt að gera samanburð á blóðsykri milli hópanna par sem of margar mælingar vantaði, einkum í viðmiðunarhópnum. Ekki var marktækur munur á fjölda grunaðra eða staðfestra sýkinga milli hópanna tveggja. Ekki var heldur marktækur munur á fjölda heilablæðinga né heilalömunar milli hópanna (tafla II).

\section{Sterameðferð á úðaformi}

Marktækt færri mæðrum barna sem fengu stera á úðaformi voru gefnir sterar fyrir fæðingu í peim tilgangi að flýta fyrir lungnaproska fóstursins en í viðmiðunarhóp $(p=0,012)$. Ekki var marktækur munur á öðrum helstu klínísku páttum milli hópanna tveggja (tafla I).

Öll börnin sem fengu stera á úðaformi fengu budesonide (Pulmicort ${ }^{\circledR}$ ). Meðgildi upphafsskammts lyfsins var $1000 \mu \mathrm{g}$ á dag (spönn 500-1200 $\mu \mathrm{g}$ á dag) Meðalaldur barnanna sem fengu innúðastera við upphaf meðferðar var 30,1 \pm 14,4 dagar (miðgildi 27,5 dagar; spönn 10-71 dagar). Meðallengd meðferðar var 43,0 $\pm 21,6$ dagar (miðgildi 38,5 dagar; spönn 8-86 dagar).

\section{Súrefnispörf og öndunaraðstoð}

Meðalsúrefnispörf barnanna sem fengu stera á úðaformi var 30,8\% (miðgildi 27,5\%; spönn 21-54\%) 5 dögum fyrir upphaf meðferðar, en hafði hækkað í 31,4\% á upphafsdegi meðferðar (miðgildi 29,5\%; spönn 21-47,3\%), p=0,77. Meðalsúrefnispörfin lækkaði jafnt og pétt frá upphafsdegi meðferðar og var lækkunin orðin marktæk
Mynd 4. Samanburður á súrefnispörf barna sem fengu sterameðferð á úđaform og barna í viðmiðunarhópi.

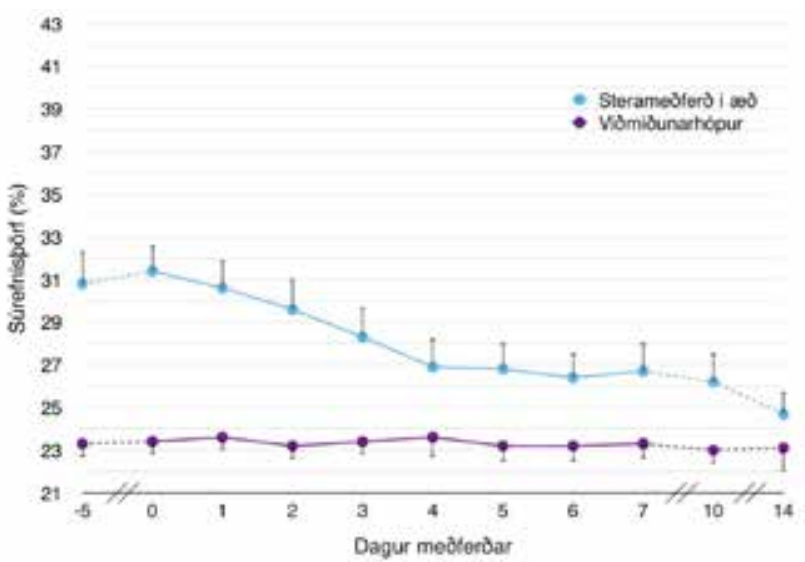

Súrefnispörf barnanna frá pví 5 dögum fyrir og par til 14 dögum eftir upphaf meðferðar. Dagur 0 er upphafsdagur meðferðar.

- Samanburður á súrefnispörf milli daga hjá meðferðarhópi: Dagur 0 og 3, p=0,009. - Samanburður á súrefnispörf meðferðarhóps og viðmiðunarhóps: Dagur -5, p<0,001; dagur 0, $p<0,001$; dagur 1, $p<0,001$; dagur 2, $<<0,001$; dagur 3, $p=0,002$; dagur 4, $p=0,03$; dagur 5, $p=0,01$; dagur 6, $p=0,01$; dagur 7, $p=0,02$; dagur 10, $p=0,02$; dagur $14, p=0,3$.

á priðja degi, 28,3\% (miðgildi 26,5\%; spönn 21-49\%), p<0,01. Fjórtán dögum eftir upphaf meðferðar var hún orðin 24,7\% (miðgildi 23,9\%; spönn 21-42\%), p<0,001. Á sama tímabili breyttist súrefnispörf barnanna í tilfellahópnum ekki marktækt.

Súrefnispörf barnanna í meðferðarhópnum var marktækt hærri en súrefnispörf barnanna í viðmiðahópnum alla dagana frá pví 5 dögum fyrir og til og með 10 dögum eftir upphaf meðferðar. Fjórtán dögum eftir upphaf meðferðar var munurinn á súrefnispörf hópanna tveggja hins vegar ekki lengur marktækur $(\mathrm{p}=0,3)$ (mynd 4).

Fimm dögum fyrir upphaf úðameðferðar voru marktækt fleiri börn í meðferðar- en viðmiðahópnum á öndunarvél (8 á móti 0; $\mathrm{p}=0,002)$ og einnig á upphafsdegi meðferðar (6 á móti $1 ; \mathrm{p}=0,035$ ). Eftir pað var munurinn milli hópanna ekki lengur marktækur.

\section{Hugsanlegar aukaverkanir}

Ekki reyndist vera marktækur munur á hugsanlegum aukaverkunum af völdum sterameðferðar á úðaformi milli hópanna.

\section{Umræður}

Áhrif sterameðferðar á lungnastarfsemi

Í rannsókninni voru áhrif barksterameðferðar á lungnasjúkdóm fyrirburanna metin með pví að kanna súrefnispörf peirra og pörf fyrir öndunarvélameðferð. Meðal barnanna sem fengu stera í æð fór súrefnispörfin vaxandi síðustu dagana áður en meðferð hófst, en minnkaði síðan marktækt næstu dagana par á eftir. Einnig fækkaði peim börnum sem purftu öndunarvélameðferð eftir að meðferð hófst, pannig að fjórum dögum síðar voru pau orðin marktækt færri en við upphaf meðferðar. Samsvarandi breytingu á súrefnispörf og pörf fyrir öndunarvélameðferð var ekki að sjá hjá viðmiðunarhópi. Pessar niðurstöður eru í samræmi við niðurstöður erlendra rannsókna sem sýnt hafa að barksterameðferð í æð 
eykur líkur á pví að fyrirburar með erfiðan lungnasjúkdóm náist af öndunarvél. $5,7,9,10$

Meðal barnanna sem fengu barkstera á úđaformi lækkaði súrefnispörfin eftir að meðferð hófst, en pó ekki eins hratt og hjá peim sem fengu barkstera í æð. Premur dögum eftir að úðameðferðin hófst var súrefnispörf barnanna í rannsóknarhópnum orðin marktækt minni en við upphaf meðferðar og 14 dögum eftir að meðferð hófst var ekki lengur marktækur munur á súrefnispörf barnanna í rannsóknarhópnum og peim í viðmiðunarhópnum. Hins vegar teljum við að of fá börn hafi verið á öndunarvél í upphafi úðameðferðar til pess að hægt sé álykta um hvort hún hafi dregið úr pörf peirra fyrir öndunarvélameðferð. Erlendar rannsóknir eru misvísandi um hvort sterameðferð í úđaformi dregur úr pörf fyrirbura fyrir öndunarvélameðferð. ${ }^{11-13}$

Súrefnispörf barnanna í viðmiðunarhópi peirra sem fengu stera í æð var marktækt meiri en barnanna í viðmiðunarhópi peirra sem fengu úðastera, sem skýrist líklega af pví að meðgöngulengd barnanna sem fengu stera í æð var marktækt styttri en barnanna sem fengu úðastera.

Nýleg rannsókn sýndi fram á að sterameðferð í úðaformi sem hafin er á fyrsta sólarhring eftir fæðingu dregur úr líkum á LLS hjá fyrirburum sem fæddir eru fyrir 28 vikna meðgöngu. ${ }^{8}$ Hins vegar benda rannsakendur á að sá ávinningur kunni að hafa verið vegna hærri dánartíðni meðal barnanna sem fengu innúđastera en peirra í viðmiðunarhópnum. ${ }^{8}$

Okkar rannsókn segir ekki til um hvort sterameðferð í æð eða í úðaformi minnkar líkur á LLS hjá fyrirburum, enda var hún ekki hönnuð til að svara peirri spurningu. Pað voru marktækt fleiri börn sem fengu greininguna LLS meðal peirra sem fengu barkstera í æð en í viðmiðunarhópnum, sem skýrist líklegast af pví að börnin sem fengu stera í æð höfðu verri lungnasjúkdóm í upphafi og voru pví líklegri til að fá LLS.

\section{Aukaverkanir}

Pyngdaraukning barnanna fyrstu tvær vikurnar eftir að meðferð hófst reyndist marktækt minni hjá börnunum sem fengu barkstera í æð en hjá viðmiðunarhópi. Hins vegar var ekki marktækur munur á pyngd hópanna við 35 vikna meðgöngualdur, sem bendir til pess að um skammtíma aukaverkun hafi verið að ræða. Minni pyngdaraukning barnanna sem fengu sterameðferð í æð á meðferðartíma gæti einnig skýrst af pví að á peim tíma voru pau veikari en börnin í viðmiðunarhópi. Ekki reyndist marktækur munur milli hópanna á öðrum hugsanlegum aukaverkunum sem kannaðar voru.

Erlendar rannsóknir hafa sýnt að barksteragjöf í æð eykur líkur á skammtíma aukaverkunum, svo sem háum blóðsykri, blæðingum í meltingarveg og garnarofi hjá fyrirburum. Einnig hafa rannsóknir sýnt fram á auknar líkur á heilalömun og annarri proskaröskun. Раð varð til pess að barnalæknafélögin í Bandaríkjunum og Kanada (American Academy of Pediatrics og Canadian Academy of Pediatrics) mæltust til pess árið 2002 að barksterar væru ekki gefnir fyrirburum nema í undantekningartilvikum og pá aðeins með upplýstu sampykki foreldra. Upphafsskammtur í flestum peim rannsóknum sem pessar leiðbeiningar voru byggðar á var 0,5-1,0 mg/kg/sólarhring. ${ }^{6}$ Í seinni tíma rannsóknum hafa hins vegar verið notaðir lægri skammtar en áður, sem virðast hafa færri aukaverkanir í för með sér. ${ }^{14}$ Nú er yfirleitt mælt með pví að nota 0,15-0,25 mg/kg/sólarhring af dexametason sem byrjunarskammt, sem síðan er minnkaður smám saman og meðferð hætt 10 dögum síðar. ${ }^{14-16}$ Einnig sýndi nýleg rannsókn að enn lægri skammtar $(0,05 \mathrm{mg} / \mathrm{kg} /$ sólarhring) minnka súrefnispörf og pörf fyrir öndunarvélameðferð hjá fyrirburum, án pess að hafa sýnilegar aukaverkanir í för með sér. ${ }^{10}$

Umræðan um hugsanleg skaðleg áhrif barkstera á proska fyrirbura virðist hafa haft áhrif á notkun peirra hér á landi, pví árin 2003 og 2004 fékk enginn fyrirburi stera í æð við erfiðum lungnasjúkdómi og pegar sú meðferð var hafin að nýju, var færri börnum gefið lyfið og lægri skammtar notaðir en áður. Petta er í samræmi við erlendar rannsóknir, sem sýnt hafa fram á minni notkun barkstera hjá fyrirburum í kjölfar ályktana bandarísku og kanadísku barnalæknafélaganna árið 2002. ${ }^{16,17}$ Árin 2005-2014 fengu að meðaltali 6,4\% allra fyrirbura á vökudeildinni sem voru $<1500$ g við fæðingu barkstera í æð við erfiðum lungnasjúkdómi og 15,5\% peirra sem voru $<1000 \mathrm{~g}$ við fæðingu. Upphafsskammtur dexametasón á sama tímabili var að meðaltali $0,2 \mathrm{mg} / \mathrm{kg} / \mathrm{sólar}-$ hring.

Erlendar rannsóknir benda til pess að aukaverkanir af sterameðferð í æð séu meiri ef meðferð hefst fyrir 7 daga aldur.7 Í okkar rannsókn hófst meðferðin í öllum tilvikum eftir að barnið var orðið vikugamalt.

Ekki reyndist marktækur munur á tíðni hugsanlegra aukaverkana milli barnanna sem fengu eingöngu innúðastera og viðmiða peirra. Öll börnin fengu budesonide (Pulmicort ${ }^{\circledR}$ ) og var upphafsskammtur lyfsins í flestum tilvikum $1000 \mu \mathrm{g}$ á dag, sem er í samræmi við skammta notaða í erlendum rannsóknum. ${ }^{18}$

\section{Styrkleikar og takmarkanir rannsóknar}

Helstu styrkleikar rannsóknarinnar eru að hún nær til heillar pjóðar, par sem öll börnin voru meðhöndluð á sömu deildinni, auk pess sem hún nær yfir tiltölulega langt tímabil (15 ár), sem gefur yfirlit yfir próun pessarar meðferðar hér á landi. Hins vegar er rannsóknin afturskyggn og skráning upplýsinga pví ekki eins ítarleg og nákvæm eins og ef um framskyggna rannsókn hefði verið að ræða.

Vel pekkt er að stúlkur sem fæddar eru fyrir tímann verða ekki eins veikar og drengir og lífslíkur peirra eru betri. Æskilegt hefði verið að para börnin milli meðferðar- og viðmiðunarhópa á kyni en vegna fárra einstaklinga í úrtaki reyndist pað ekki hægt.

Við mat á hugsanlegum áhrifum sterameðferðar á proska barnanna var kannað hvort pau hefðu greinst með heilalömun. Nákvæmara hefði verið að nota jafnframt aðra nálgun, svo sem Bayley-proskamat, en ekki var byrjað að gera slíkt mat á fyrirburum á Barnaspítalanum fyrr en undir lok rannsóknartímabilsins. Vegna pessa og pess að úrtakið er frekar lítið, teljum við að ekki sé rétt að draga ályktanir um langtímaáhrif stera á proska fyrirbura út frá pessari rannsókn. 
Lokaorð

Rannsókn pessi leiddi í ljós að gjöf barkstera í æð dregur marktækt úr súrefnispörf fyrirbura með erfiðan lungnasjúkdóm fyrstu dagana eftir að meðferð hefst og minnkar jafnframt pörf peirra fyrir öndunarvélameðferð, án verulegra aukaverkana. Eina marktæka aukaverkunin sem fram kom var tímabundin skerðing á pyngdaraukningu barnanna. Teljum við pví að til greina komi, undir sérstökum kringumstæðum, að gefa fyrirburum með erfið- an lungnasjúkdóm barkstera í æð. Leggjum við til að pað sé aðeins gert ef sýnt er að ekki takist að ná börnunum af öndunarvél nema gripið sé til pessarar meðferðar. Steragjöf á úðaformi virðist einnig draga úr súrefnispörf barnanna án merkjanlegra aukaverkana. Pví kemur einnig til greina að gefa fyrirburum stera á úðaformi undir vissum kringumstæðum, svo sem til að koma í veg fyrir að börn með vaxandi súrefnispörf purfi á öndunarvélameðferð að halda.

\section{Heimildir}

1. Wert S. Normal and abnormal structural development of the lung. In: Polin RA FW, Abam SH, editor. Fetal and neonatal physiology. Saunders, Philadelphia 2004: 783801

2. Clark RH, Gerstmann DR, Jobe AH, Moffitt ST, Slutsky AS, Yoder BA. Lung injury in neonates: causes, strategie for prevention, and long-term consequences. J Pediatr 2001; 139: 478-86.

3. Jobe AH, Bancalari E. Bronchopulmonary dysplasia. Am J Resp Crit Care Med 2001; 163: 1723-9.

4. Baraldi E, Filippone M. Chronic lung disease after premature birth. N Engl J Med 2007; 357: 1946-55.

5. Doyle LW, Ehrenkranz RA, Halliday HL. Late ( $>7$ days) postnatal corticosteroids for chronic lung disease in preterm infants. Cochrane Datab Syst Rev 2014; 5: Cd001145.

6. Postnatal corticosteroids to treat or prevent chronic lung disease in preterm infants. Pediatrics 2002; 109: 330-8

7. Doyle LW, Ehrenkranz RA, Halliday HL. Early ( $<8$ days) postnatal corticosteroids for preventing chronic lung disease in preterm infants. Cochrane Datab Syst Rev 2014; 5 . Cd001146.

8. Bassler D, Plavka R, Shinwell ES, Hallman M, Jarreau $\mathrm{PH}$, Carnielli V, et al. Early Inhaled Budesonide for the Prevention of Bronchopulmonary Dysplasia. N Engl J Med 2015; 373: 1497-506.
9. Doyle LW, Ehrenkranz RA, Halliday HL. Dexamethasone treatment after the first week of life for bronchopulmonary dysplasia in preterm infants: a systematic review. Neonatology 2010; 98: 289-96.

10. Yates HL, Newell SJ. Minidex: very low dose dexamethasone $(0.05 \mathrm{mg} / \mathrm{kg} /$ day $)$ in chronic lung disease. Arch Dis Child Fetal Neonatal Ed 2011; 96: F190-4.

11. Cole $\mathrm{CH}$, Colton $\mathrm{T}$, Shah BL, Abbasi S, MacKinnon BL, Demissie S, et al. Early inhaled glucocorticoid therapy to prevent bronchopulmonary dysplasia. N Engl J Med 1999; 340: 1005-10.

12. Jonsson B, Eriksson M, Soder O, Broberger U, Lagercrantz $\mathrm{H}$. Budesonide delivered by dosimetric jet nebulization to preterm very low birthweight infants at high risk for development of chronic lung disease. Acta Paediatrica (Oslo, Norway: 1992) 2000; 89: 1449-55.

13. Jangaard KA, Stinson DA, Allen AC, Vincer MJ. Early prophylactic inhaled beclomethasone in infants less than $1250 \mathrm{~g}$ for the prevention of chronic lung disease. Paediatr Child Health 2002; 7: 13-9.

14. Doyle LW, Davis PG, Morley CJ, McPhee A, Carlin JB. Outcome at 2 years of age of infants from the DART study: a multicenter, international, randomized, controlled trial of low-dose dexamethasone. Pediatr 2007; 119: 716-21.
15. Doyle LW, Davis PG, Morley CJ, McPhee A, Carlin JB. Low-dose dexamethasone facilitates extubation among chronically ventilator-dependent infants: a multicenter, international, randomized, controlled trial. Pediatr 2006; 117: $75-83$.

16. Jefferies AL, Canadian Paediatric Society F, Newborn C. Postnatal corticosteroids to treat or prevent chronic lung disease in preterm infants. Paediatr Child Health 2012; 17: 573.

17. Walsh MC, Yao Q Horbar JD, Carpenter JH, Lee SK, Ohlsson A. Changes in the use of postnatal steroids for bronchopulmonary dysplasia in 3 large neonatal networks. Pediatr. 2006; 118: e1328-35.

18. Pantalitschka T, Poets CF. Inhaled drugs for the prevention and treatment of bronchopulmonary dysplasia. Pediatric Pulmon 2006; 41: 703-8.

\section{ENGLISH SUMMARY}

\section{Postnatal corticosteroids in preterm infants with immature lung disease}

Erna Hinriksdóttir ${ }^{1}$, Hrólfur Brynjarsson², Pórður Pórkelsson ${ }^{1,2}$

Introduction: Corticosteroids have been used in preterm infants with immature lungs to decrease their need for supplemental oxygen and mechanical ventilation. Whether the benefits of the treatment outweigh possible adverse effects remains controversial. The main objective of the study was to evaluate the effects of intravenous and inhalation corticosteroids on preterm infants' need for supplemental oxygen and mechanical ventilation and potential adverse effects.

Material and methods: This was a retrospective cohort study on preterm infants at the Neonatal Intensive Care Unit of Children's Hospital Iceland, born between 2000-2014 and treated with intravenous $(n=28)$ or inhalation $(n=30)$ corticosteroids for immature lung disease. For each infant receiving steriods one infant who did not receive steriods was selected as control, matched on gestational age.

Results: There was a significant decrease in the need for supplem- ental oxygen following intravenous and inhalation corticosteroids administration, and a significant decrease in the need for mechanical ventilation following intravenous corticosteroids administration, but not in controls. Infants receiving intravenous corticosteroids gained significantly less weight than controls during treatment, but no significant difference in weight between groups was found at 35 weeks postmenstrual age, or in other possible adverse effects such as the prevalence of cerebral palsy.

Conclusion: Intravenous and inhalation corticosteroids decrease the need for supplemental oxygen in preterm infants with immature lung disease and intravenous steriods facilitate earlier weaning from mechanical ventilation, without significant adverse effects. Therefore, it seems justifiable in selected cases to use corticosteroids in treatment of preterm infants with severe immature lung disease.

'University of Iceland, Faculty of Medicine, ${ }^{2}$ Children's Hospital Iceland.

Key words: Corticosteroids, preterm infants, chronic lung disease, mechanical ventilation.

Correspondence: Pórður Pórkelsson, thordth@landspitali.is 